\title{
Government Policies To Improve Tobacco Farmers Business Results
}

\author{
Hezron Sabar Rotua Tinambunan ${ }^{1 *}$ and Hananto Widodo ${ }^{2}$ \\ ${ }^{1}$ Faculty of Law and Social Sciences, State University of Surabaya, Surabaya, East Java, Indonesia
}

\begin{abstract}
Warehouse Receipt System suggest the potential that can be utilized on the implementation of the Warehouse Receipt System primarily in support of the financing, the minimization of price fluctuations, increase farmers' income, credit mobilization, improvement of product quality and so on. However, implementation of warehouse receipt system in the agricultural sector is still faced a number of obstacles including transaction costs, inconsistencies in the quantity and quality of agricultural products, the lack of support banking institutions, and the still weak farmer institutions. With institutional farmers are not organized properly, the rules of the warehouse receipt system is still seen as too complicated so that the necessary simplification of procedures so that the warehouse receipt system could be used by farmers. In addition, the socialization of the Warehouse Receipt System and conducive government policy support will be an important factor so that the warehouse receipt system can be implemented optimally.
\end{abstract}

\section{Introduction}

Empowerment and guidance to farmers and small and medium enterprises based on agriculture, many alternative programs that can be scheduled, both relating to capital programs, facilities and infrastructure, the production process, up to the marketing problems and other issues. In terms of providing a solution to the problem of capital, is one of the warehouse receipt to obtain financing solutions with the assurance of agricultural commodities stored in warehouse.[1]

The phenomenon of the fall in prices of agricultural commodities, especially during the harvest, sometimes even almost certainly be a phenomenon that is very detrimental to farmers. In terms of future harvests be eagerly awaited by farmers, because at the time that they hoped to enjoy his labor by means of immediately selling a commodity crops.[2] What about to say, if it later becomes during the fall harvest season prices, which was triggered by the enactment of economic law, namely the law of the balance between demand and supply of a commodity. At the same time farmers want to sell their crops as soon as urged by the need for cash, either for refund agricultural venture capital and operational funding cost of living. To overcome this problem and can also help finance the efforts of farmers, the government then arrange business financing schemes through various agriculture schemes, one of which is the scheme of the Warehouse Receipt System.[3]

\footnotetext{
${ }^{*}$ Corresponding author : hezron_110288@yahoo.co.id
} 
Problems that plagued farmers seemingly non financiers should not be ignored, because if negligible impact negatively affect developing the agricultural sector and reduce the competitiveness of the sector. Their access to capital as required by the transaction's costs as well as administrative procedures easier for farmers to improve productivity and product quality.[4]

In obtained a credit facility, both from the formal or informal sector, a number of farmers face many obstacles, among others: (1) farmers do not have the collateral in the form of fixed assets such as proof of ownership of land and buildings, (2) the existence of bureaucracy and administration of credit relative convoluted that complicate the farmers, (3) the lack of experience of some particular banks in serving the population in rural areas, (4) the high transaction costs of loans from the informal sector, (5) the high degree of risk associated with the entrepreneur/small producers, (6) dependence on the ability of government's formal sector.[5]

Empowerment and coaching to principals small and medium industries in which there are farmers and peasant workers, warehouse receipts is one-one solution to obtain financing to guarantee the commodity stored in the warehouse, such as agricultural commodities, plantation, forestry, agricultural, fertilizers and pesticides, handicrafts and so on. In Indonesia, the system is a longstanding through Warehouse Receipt Financing where PT. Sucofindo and PT. Bhanda Ghara Fund as collateral manager, and Indonesian exporters obtain credit from foreign banks with collateral commodity. Efforts are being made is that domestic banks can play a role in the scheme of the warehouse receipt.[6]

One of the problems in the agricultural sector is still long chain of agricultural trade system, causing farmers can not enjoy a better price. This is because traders have taken too large profit from the sale. With built Warehouse Receipt System it can be one solution to all problems faced by the farmers in terms of sales.

East Java Provincial Government has issued Regional Regulation of East Java Province Number 14 Year 2013 on Accelerating the Implementation of Warehouse Receipt, the consideration that one of the objectives of economic development of agricultural areas focused on efforts to promote the welfare of farmers through the provision of control instruments commodity sales at current prices down as well as financing instruments to increase the capacity of capital through the Warehouse Receipt System; and that the implementation of the Warehouse Receipt System in East Java province still needs to be accelerated efforts are coordinated systematically given the still large untapped potential to the maximum.

Regional regulations are expected to provide certainty to the economy of farmers who have less received attention from the government, especially for salt farmers and tobacco going through adversity because entangled in debt bondage system. Ali Mudji, admitted that during this time both the salt and the tobacco farmers often collapsed abundant harvest time arrives. This is because they have no place to store it. As a result, the harvest sold cheaply to middlemen, it is no wonder if their lives were far from maturity despite their abundant products. See this reality, then the Regional Commission of the Regional Receipt System. Of course not all the salt and tobacco and immediately able to enter the Warehouse Receipt System. The goods must pass the quality standards set by the Association of Farmers. So the quality and quantity of crops that enter the warehouse with the Warehouse Receipt System fixed price can be maintained, so that farmers do not feel disadvantaged.

The results of several studies on the Warehouse Receipt System suggest the potential that can be utilized on the implementation of the Warehouse Receipt System primarily in support of the financing, the minimization of price fluctuations, increase farmers' income, credit mobilization, improvement of product quality and so on. However, implementation of warehouse receipt system in the agricultural sector is still faced a number of obstacles 
including transaction costs, inconsistencies in the quantity and quality of agricultural products, the lack of support banking institutions, and the still weak farmer institutions. With institutional farmers are not well organized, the warehouse rule is still the receipt system so that the warehouse receipt system could be used by farmers. In addition, the socialization of warehouse receipt system and conducive government policy support will be an important factor that warehouse receipt system can be implemented optimally.

Departing from the background as described above is the "Government Policies To Improve Tobacco Farmers Business Results".

\section{Problem}

Based on the explanation, as described in the Background section, the formulation of the problem is the focus of this study are as follows:

What policies and how the substance of the policies implemented in the framework of a tobacco farmer community empowerment through the Warehouse Receipt System in the face of the Asean Economic Community free market?

\section{Discussion}

The government tried to give some policy efforts in helping the lives of farmers. For example in the area of Situbondo and Banyuwangi, the offers include programs providing capital assistance through PNPM program. Situbondo Regency Government itself also has cooperative loans of about USD 10 million, - up to Rp 30 million, as the stimulation of venture capital for tobacco farmers. The government also provides assistance in the form of agricultural machinery which is given annually in the form of tractors, power spayer, water pumps, engines and so on. But until the study was conducted, in the period 2015 there has been no assistance from the local government, either in the form of capital and agricultural machinery directly to farmers. Providing assistance in 2015 , is given only to groups or institutions that are legal entities.

The assistance provided by the government so far with NPK fertilizer, although there are already some kind of assistance from the government, but the farmers claim to still have a problem of capital difficulties. The difficulty of capital is usually circumvented by forced to borrow money from a middleman, which ultimately will entail the sale of agricultural products by way of swing, so the selling price of the harvest will be very low. Explanation of farmers from the interview are as follows.

Mr. Niawi said :

"The role of the government has been providing capital loans to the community here for plant tobacco from PNPM. But it must have a guarantee like BPKB, land letter, or the like. If you do not have those letters you will not get a loan. But if the tobacco farmer fails to harvest and can not return the loan to PNPM, it will not get a loan anymore despite having all kinds of required letters"

Mr. Jailani said :

"The government provides NPK fertilizer assistance to grow tobacco"

Based on information obtained from the Department of Industry and Trade District Lumajang, Lumajang district, in 2015, carried out activities of the Partnership for Small and Medium Enterprises (SMEs) to large businesses in Raw Material Procurement. This policy is basically aimed to create a relationship of mutually beneficial cooperation between SMEs of farmers or craftsmen tobacco with large businesses in the procurement of raw materials, increasing quality of tobacco chopped as needed large businesses (manufacturers), increased knowledge, insight, farmers / artisans in processing the tobacco after post-harvest and 
increasing the market access of tobacco Lumajang out area. More fully, some of the policies that have been implemented are the following services:

a. 2015 implementation of the activities of the Partnership for Small and Medium Enterprises (SMEs) to large businesses in Raw Material Procurement.

The purpose of this activity:

1. The creation of mutually beneficial partnerships between SMEs and farmers/artisans tobacco with large businesses in the procurement of Raw Materials

2. Increasing the quality of tobacco Rajang as needed large businesses (manufacturers)

3. Increased knowledge, insight, farmers / artisans in tobacco after post-harvest processing

4. Increased market access of tobacco Lumajang out area

Other forms of activities is in the form of a meeting between SME Business partners Craftsman / Tobacco Growers with great effort in the procurement of raw materials followed by a field trip / location to place the management / pengrajangan tobacco in some tobaccoproducing region.

1. These activities are carried out through cooperation Department of Industry Kab. Lumajang together APTI Kab. Lumajang, APTI Central Java, collectors Tobacco PT. Kusuma Kab. Klaten district of Central Java and APTI. Klaten / collectors Tobacco (CV. Krabat).

2. Implementation also cooperation Department of Industry Kab. Lumajang together APTI Kab. Lumajang

b. 2014 also implemented the Partnership activities Small and Medium Enterprises (SMEs) to large businesses in Raw Material Procurement. These activities bring together farmers / artisans tobacco Lumajang with big businesses / manufacturer of cigarettes in the district. Temanggung Central Java and Tulungagung Java. The goal is Enhancing Partnerships between tobacco farmers with tobacco industry / factory Smoking / Tobacco Employers in order to meet the request of the manufacturer / factory Smoking / Tobacco Employers regarding the quality and quantity of the recommended / required by cigarette manufacturers / Entrepreneur Tobacco.

c. In 2013, the Partnership activities undertaken also Small and Medium Enterprises (SMEs) to large businesses in Raw Material Procurement. These activities bring together farmers / artisans tobacco Lumajang with big businesses / manufacturer of cigarettes in PT Needles District. Kudus in Central Java.

d. In addition, implementation of the Technical Guidance: Improving the quality of tobacco products held by the Department of Industry Department of Industry District of East Java. Lumajang in terms of reducing the levels of tar and nicotine.

In addition, based on interviews with Department of Plantation District, Lumajang, obtained information that Disbun provided training and assistance to tobacco farmers related plants, the use of technology to post-harvest. To support and develop the tobacco commodities in Lumajang, Forestry and Plantation has held activities include: 
1. Assessment of applied technology for the tobacco development

2. Guidance intensification of tobacco

3. Development of farmer groups

4. Help Working capital equipment

\section{Conclusion}

Results of a study of the warehouse receipts in East Java province, two counties that have a warehouse receipt, i.e., Situbondo. Warehouse receipt contained in Situbondo can only be used only in agricultural commodities and plantations with the type of plant that has been determined by a decision of the Minister of trade in the form of grains, rice, corn, seaweed, cocoa, pepper, sugarcane and rubber.

\section{Recommendation}

Researchers recommend policies regarding tobacco warehouse receipt system to conduct an assessment of the tobacco plant as well as the economic value to be included in the agricultural commodities that can be stored in warehouses in the administration of the warehouse receipt system; This will have an impact on changes in Regulation of the Minister of Trade (Regulation) No. 26 / M-DAG / PER / 6/2007 that currently there are eight types of agricultural commodities.

\section{References}

1. J. Coulter, G. Onumah, Food Policy, 27:4 (2002)

2. P. Stopka, D. W. Mcdonald, Ethology, 105:11 (1999)

3. N. N. Towo, P. J. Kimoro, IJECM, 2:7 (2014)

4. A. M. Shelton, JDS, 43:5, 890-900 (2007).

5. G. Feder, R. Birner, and J. R. Anderson, JADEE, 1:1, 31-245 2011.

6. H. Youheng and Z. Xiaohong, Risk Control of Logistics Enterprise in Warehouse Receipt Pledging, in Proceedings of 2008 International Conference on Logistics Engineering and Supply Chain, 2008. 